\title{
Fluxo das Exportações Brasileiras de Cachaça: traços da influência do Estado no setor ${ }^{1}$
}

\author{
André Luiz de Paiva², Rosália Beber de Souza ${ }^{3}$, \\ Ikaro Daniel de Carvalho Barreto ${ }^{4}$ e Mozar José de Brito ${ }^{5}$
}

Resumo: A cachaça é considerada uma bebida genuinamente brasileira, produzida em todo o território nacional e exportada para todos os continentes. Dada a sua relevância, propõe-se, neste trabalho, descrever o fluxo das exportações da bebida, destacando os países importadores e estados produtores, bem como a influência das políticas públicas e dispositivos legais de incentivo à produção/comércio da bebida. Para tal estudo, considerou-se uma amostragem de 1997 a 2015, classificando-a entre os períodos das gestões dos governos de Fernando Henrique Cardoso, Luís Inácio Lula da Silva e Dilma Rousseff, de modo que se pudesse analisar a evolução das exportações a partir da formação de grupos, ou clusters, dos países importadores com base nos três períodos analisados. Os resultados apontaram que as exportações da cachaça brasileira e, por conseguinte, os mercados consumidores, têm aumentado no decorrer dos anos, sendo tal fenômeno relacionado à atuação do Estado na cadeia produtiva da bebida.

Palavras-chaves: exportações, cachaça, governo FHC, governo Lula, governo Dilma, análise de clusters.

Abstract: Cachaça is considered a genuine Brazilian drink, produced throughout the country and exported to all continents. Given its importance, it is proposed in this paper to describe the stream of the exports, highlighting the importers and producing states, as well as the influence of public policies and legal provisions to encourage the production / trade of this drink. For this study, it was considered a sampling from 1997 to 2015, ranking it among the periods of the administrations of the governments of Fernando Henrique Cardoso, Luis Inácio Lula da Silva and Dilma Rousseff, so that the evolution of exports from forming groups, or clusters, of importing countries based on three periods analyzed, could be evaluated. The results showed that Brazilian cachaça exportations and

1. Data de submissão: 25 de abril de 2016. Data de aceite: 21 de julho de 2017.

2. Universidade Federal de Lavras. Lavras, Minas Gerais, Brasil. E-mail: andrepaiva2@gmail.com

3. Universidade Federal de Viçosa. Viçosa, Minas Gerais, Brasil. E-mail: rosaliabeber@ufv.br

4. Universidade Federal Rural de Pernambuco. Recife, Pernambuco, Brasil. E-mail: daniel.carvalho.ib@gmail.com

5. Universidade Federal de Lavras. Lavras, Minas Gerais, Brasil. E-mail: mozarbrito@gmail.com 
consumer markets have increased over the years, and this phenomenon is related to the state's role in the production chain of this drink.

Key-words: exports, cachaça, government of FHC, government of Lula, government of Dilma, analysis of clusters.

Classificação JEL: F13.

DOI: http://dx.doi.org/10.1590/1234-56781806-94790550407

\section{Introdução}

A cachaça é uma bebida alcoólica centenária fabricada a partir da fermentação e destilação do caldo ou mosto da cana-de-açúcar. Sua produção é dividida entre unidades produtivas industriais e artesanais localizadas em todo o território nacional, sendo considerada um símbolo da cultura brasileira (SILVA, 2009).

Dados do Instituto Brasileiro da Cachaça (IBRAC, 2016) estimam que a produção anual do destilado é de aproximadamente 800 milhões de litros, distribuídos entre 15 mil estabelecimentos. Ressalta-se que, desse total, apenas 2 mil organizações estão devidamente registradas na Receita Federal, configurando, então, um quadro de cerca de $90 \%$ de produtores informais. Dentre os estados fabricantes, destacam-se: São Paulo, Pernambuco, Ceará, Minas Gerais e Paraíba.

Apesar do alto índice de informalidade, a cadeia produtiva da cachaça tem passado por uma série de transformações de ordem institucional e política (sobretudo a partir da década de 1980). Estas mudanças influenciaram um movimento de reposicionamento da bebida, considerada anteriormente como um produto de baixo valor simbólico, em um bem de grande potencial econômico e inserção no mercado externo, sendo, em alguns casos, uma bebida que sinaliza um alto status social ao consumidor (BRAGA e KYIOTANI, 2015).

Estas transformações estão relacionadas diretamente à organização de grupos de produtores e ao papel do Estado. Estes atuaram no reconhecimento e institucionalização de normas e práticas que auxiliaram na construção do mercado da cachaça, especial- mente as ações e estratégias voltadas à exportação da bebida (COUTINHO, 2001; CHALITA e SILVA, 2010).

No que se refere ao papel do Estado nesse processo, destacam-se duas iniciativas: a criação do Programa Brasileiro de Apoio à Aguardente, Caninha e Cachaça (PBDAC), em 1997, e a promulgação do Decreto no 4.062 de 21 de dezembro de 2001, que 'define' a cachaça como uma indicação geográfica do País e estabelece normas necessárias para a produção do destilado. Tais políticas, conforme Silva (2009) foram fundamentais para a formação de uma estrutura produtiva qualificada e para o fortalecimento do comércio da bebida no mercado externo.

A cachaça é exportada e consumida em mais de 60 países, distribuídos entre todos os continentes, tendo movimentando, em 2015, US\$13,32 milhões e 7,77 milhões de litros (IBRAC, 2016). No entanto, ainda que existam trabalhos que abordem a questão, estes números e indicadores têm sido pouco explorados. Sobretudo ao se analisar uma perspectiva histórica e a influência de políticas públicas voltadas ao setor, torna-se relevante questionar: qual é o fluxo das exportações da cachaça brasileira, considerando a influência do Estado nas últimas duas décadas, demarcadas por governos distintos e políticas externas direcionadas à cadeia produtiva?

Neste sentido, este trabalho tem como objetivo principal: descrever o fluxo das exportações da cachaça brasileira nos períodos dos governos de Fernando Henrique Cardoso (considerando os anos de 19972002), Luís Inácio Lula da Silva (2003-2010) e Dilma Rousseff (2011 até 2015). De modo específico, buscou- 
-se: (i) identificar os valores (em Reais), quantidade (em litros) e peso (em quilogramas) das exportações da bebida entre os anos 1997 a 2015; (ii) identificar os países importadores; (iii) classificar os valores conforme os períodos dos governos Fernando Henrique Cardoso (FHC), Luís Inácio Lula da Silva (Lula) e Dilma Rousseff (Dilma); (iii) agrupar os países importadores, em cada período, mediante análise de conglomerados (clusters) e (iv) discutir traços da influência do Estado no perfil das exportações e na formação dos grupos de importadores.

A título de elucidação do estado da arte nesta temática, ressalta-se que outros pesquisadores têm se interessado pelo volume de exportações de cachaça, sobretudo a partir de 2000. Ceribeli et al. (2010) analisam as exportações da bebida de 1998 a 2009 e indicam que a institucionalização de legislações específicas ao setor tem influenciado no crescimento do volume de transações para o mercado externo. Estes autores discutem o indicador de orientação regional nas exportações direcionadas à Alemanha e Estados Unidos e destacam que mais investimentos de natureza organizacional e estatal são necessários para consolidar este mercado. Da mesma forma, Oliveira Neto (2005) apresenta o panorama de exportações da bebida de 1996 a 2004 e evidencia uma tendência de crescimento positiva. Todavia, argumenta que, para melhor estabelecer este mercado, é necessário estimular o associativismo, incentivar uma mudança na cultura empresarial direcionada ao mercado externo, adequar a carga tributária de modo justo e envolver atores governamentais e órgãos de representação do setor. Além disso, o autor propõe uma estratégia de inserção internacional direcionada aos produtores do estado de Pernambuco. Adiante, Verdi (2006) discute as perspectivas para exportações do destilado entre 2000 e 2006 e afirma que, em virtude da quantidade produzida no País, pouco foi exportado. Segundo a autora, estes resultados foram devidos à carência de mecanismos de incentivo à atividade e qualificação dos produtores. Assim, propõe que o crescimento nas transações tende a aumentar conforme os fabricantes se engajem em atividades associativas e cooperativas, coordenadas por agentes do Estado. Verdi (2006) destaca ainda o papel do estado de São Paulo na composição do fluxo de exportações e o potencial de negociação da cachaça artesanal neste mercado devido ao seu maior valor agregado.
Nesta direção, Silva (2007) investiga as exportações no período de 1996 e 2006 e afirma que o crescimento dos valores negociados foi tímido, indicando que as transações foram subvalorizadas considerando o potencial de consumo da bebida. Este quadro pode mudar, conforme o autor, à medida em que seja agregado maior valor na produção do destilado. Por sua vez, o tema do comércio exterior envolvendo a cadeia produtiva da cachaça foi explorado qualitativamente por Chalita e Silva (2010). Os autores reconhecem o baixo desempenho das exportações e advogam que a dualidade entre padronização e identidade da bebida, permeada pela carga tributária e características do mercado internacional, são os responsáveis por este quadro. Desta forma, entendem que sobretudo investimentos na imagem da cachaça de alambique podem auxiliar na reconstrução do mercado consumidor externo do destilado.

A diferença deste trabalho com os demais estudos supramencionados é que este avança nas discussões envolvendo o perfil das exportações de cachaça à medida em que articula a influência das políticas públicas do setor e da política de comercio exterior neste panorama. Também contempla uma ampla série histórica das exportações do setor, de 1997 a 2015, permitindo uma análise de maior completude do comércio exterior da bebida, já que na literatura há escassez de informações sobre o assunto. Ademais, foram classificados os grupos de países importadores mediante análise multivariada dos dados. A análise de conglomerados, ou clusters, tem sido empregada em outros estudos envolvendo comércio internacional (GOMES, SOUZA e GAZZOLA, 2009, FIRME e VASCONCELOS, 2015), embora ainda não tenha sido aplicada ao mercado da cachaça. Entende-se que esta análise permite melhor visualização do perfil dos países importadores, o que pode implicar no direcionamento das exportações e na atuação do Estado na política comercial.

Além da introdução (1), este trabalho está estruturado em mais quatro seções: apresentação da fundamentação teórica (seção 2), que discute as características e marcos institucionais da configuração do setor produtivo da cachaça, bem como direcionamentos da política externa brasileira voltada ao setor no período estudado; descrição dos procedimentos metodológicos (seção 3); apresentação dos resultados encontrados e as discussões pertinentes (seção 4) e as considerações finais do trabalho (seção 5). 


\section{Fundamentação teórica}

\subsection{O contexto sócio-histórico da produção de cachaça}

A produção de cachaça no Brasil iniciou-se no período colonial, por volta do século XVI, e foi um importante bem comercial à época, ainda que majoritariamente destinado ao consumo interno. Alguns produtores, porém, utilizavam a aguardente de cana como moeda de troca no mercado de escravos, de modo que realizavam transações com o mercado externo. A produção e a comercialização muitas vezes eram realizadas à margem da lei, em pequenos estabelecimentos. Apesar de registros de consumo e embriaguez na elite local, os principais consumidores eram escravos e brancos pobres (SOUZA, 2004).

Entretanto, devido à rápida expansão de engenhos, a produção da cachaça foi proibida pela Coroa por desviar a mão de obra das operações principais do período. Outra medida restritiva foi promulgada no Rio de Janeiro, em 1649, proibindo a fabricação da aguardente de cana. Contudo, tais ações governamentais tiveram pouco impacto e a população não diminuiu seu consumo, de modo que a resposta do Estado foi a criação dos primeiros mecanismos de tributação da bebida (COUTINHO, 2001).

Durante o século XIX e o início do século XX, a cachaça tornou-se largamente difundida em território nacional, ainda consumida, principalmente, pelas camadas mais populares, embora existisse uma preferência pela bebida produzida em regiões específicas (CHALITA e SILVA, 2010). Nesse período, contudo, permanecia o interesse em controlar o comércio e a produção da bebida, motivado por questões fiscais e pelo receio da embriaguez desregrada, sobretudo quando relacionado ao preconceito contra as classes marginais da sociedade (SOUZA, 2004).

Conforme Castro, Athayde e Palma (2010), até o final da Segunda Guerra Mundial, o modelo de produção artesanal predominava no País. Contudo, a diminuição da produção de açúcar em engenhos, bem como inovações tecnológicas de 1945 a 1960, fomentaram a industrialização do processo. Assim, foram criadas as primeiras plantas industriais de fabricação de cachaça em grande escala. Após esse período, a cadeia produtiva da aguardente de cana passou a ser influenciada por dois fatores: o primeiro, relacionado às mudan- ças no ciclo produtivo da cana de açúcar, o que levou à concentração das atividades de junho a novembro, gerando um período de capacidade ociosa no setor; e o segundo, referente à variação dos preços do álcool e do açúcar no mercado, que gerou necessidade de maior especialização das atividades e atores envolvidos na cadeia produtiva da cachaça (SOUZA e VALLE, 2004). Nesse período, também são ressaltados os mecanismos de tradição implementados durante o governo Vargas, na década de 1930, por meio do Instituto do Açúcar e do Álcool (IAA). Estas medidas de caráter restritivo e punitivo dificultavam a formalização de nova unidades produtivas artesanais (COUTINHO, 2001).

Entretanto, a partir da década de 1980, diversas ações e políticas foram desenvolvidas com o intuito de diferenciar a produção e mobilizar o reposicionamento da aguardente de cana a uma demanda crescente por produtos de melhor qualidade (SOUZA e VALLE, 2004). Inicialmente, no ano de 1982, pesquisadores do Instituto de Desenvolvimento Industrial de Minas Gerais (INDI) elaboram um projeto para avaliar o cenário corrente e o potencial da produção de cachaça no estado (SILVA, 2009). Segundo Coutinho (2001), os resultados mostraram um ambiente caracterizado por rendimento agrícola ineficiente, carência de novas tecnologias e pouca estrutura para comercialização, ainda que existisse a demanda por produtos de qualidade maior, interessada em pagar um preço maior pela bebida. Dessa forma, esse relatório apontava também para a possiblidade de investimento no setor, sobretudo no subsistema artesanal, de modo que foi desenvolvido um projeto de fabricação de uma variedade da bebida tomando como referência estudos realizados na Escola Superior de Agricultura "Luiz de Queiroz" da Universidade de São Paulo (ESALQ/USP). $\mathrm{O}$ instituto procurou agregar o conhecimento científico às características culturais do estado e ao modo de produção tradicional, de modo que a aguardente artesanal de Minas Gerais fosse fundamentada em qualidade e tradição (SOUZA e VALLE, 2004).

Além disso, a partir da década de 1990, no âmbito governamental, ainda em Minas Gerais, foram criados programas e políticas voltadas ao desenvolvimento desse segmento, tais como o Programa Mineiro de Incentivo à Produção de Aguardente (Pró-cachaça), criado pela Lei Estadual no 10.853 , de 04 de agosto de 1992 e regulamentado pelo Decreto no 34.645, de 14 abril de 1993. O Pró-cachaça teve como objetivo 
fomentar a construção de um produto regional com maior valor de mercado por meio da oferta de crédito especial para que produtores rurais criassem ou investissem em alambiques e processos de produção da cachaça artesanal (SILVA, 2009). Assim, é possível entender que, por meio dessas ações do governo do estado de Minas Gerais durante as décadas de 1980 e 1990, uma série de outras iniciativas tanto de interesse privado quanto público foram desenvolvidas, alcançando a esfera do governo federal. Adiante, serão discutidas tais iniciativas, destacando aspectos da política comercial dos governos do período.

\subsection{A atuação do Estado Nacional na cadeia produtiva da cachaça e os direcionamentos da política externa nos governos FHC, Lula e Dilma Rousseff}

Apesar da existência de normas e legislações específicas em cada estado, o governo federal foi um importante ator na configuração da cadeia produtiva da cachaça brasileira. O Estado atuou sobretudo como agente da institucionalização e normatização de processos voltados à melhoria da qualidade e exportações do destilado.

A primeira dessas iniciativas refere-se ao reconhecimento legal do termo "cachaça" por meio do Decreto no 2.314 de 1997, posteriormente reformulado a partir do Decreto no 6.871 de 2009. Nesse mesmo período, inspirado no Pró-cachaça (política pioneira no oferecimento de crédito e subsídios à produção de cachaça em Minas Gerais), surge o Programa Brasileiro de Desenvolvimento da Aguardente, Caninha e Cachaça (PBDAC). Esta política foi desenvolvida no interior da Associação Brasileira de Bebidas (Abrabe) e apresentada em 1997 com a participação de produtores e do governo federal por meio dos Ministérios da Agricultura, Pecuária (Mapa) e Abastecimento, do Desenvolvimento, Indústria e Comércio Exterior (MDIC) e da Ciência e Tecnologia (MCT). O PBDAC teve como objetivos principais: afirmar e valorizar a cachaça como um produto genuinamente nacional e capacitar o setor à inserção e competição internacional (SOUZA e VALLE, 2004).

Adiante, destaca-se o Decreto no 4.062/2001 que define a expressão "cachaça do Brasil" como indicação geográfica do País (BRASIL, 2001). Segundo Silva (2009), esse decreto procurou garantir aos produto- res "maior segurança para investirem em propaganda no exterior e na própria produção, além do respaldo jurídico para questões relativas à exportação" (p. 36). Siqueira e Dias (2013) argumentam que essas ações foram concretizadas devido a mudanças culturais lentas e profundas. Nesse sentido, a aguardente de cana, antes relacionada às classes marginais e taxada como bebida de baixo valor passou a ser reconhecida como símbolo da identidade e cultura brasileira.

A partir desse decreto, diversas ações voltadas à construção de um padrão de qualidade para a bebida foram desenvolvidas, tais como a fundação da Câmara Setorial da Cadeia Produtiva da Cachaça, em 2004, e a fundação do Instituto Brasileiro de Cachaça (Ibrac) em 2006. Tais instituições foram de grande importância para a criação e normatização de sistemas de qualidade e certificação da bebida (SILVA, 2009).

Mais à frente, durante o governo Dilma Rousseff, destaca-se o acordo bilateral firmado entre Brasil e Estados Unidos em 2012, e publicado em abril de 2013. Nesse acordo os EUA passaram a reconhecer a indicação de origem nacional da cachaça, antes classificada como "rum brasileiro". Conforme Siqueira e Dias (2013), tal medida representou um importante avanço simbólico na inserção da cachaça como produto brasileiro no mercado externo.

Nesta direção, observa-se que a ação do governo federal por meio de políticas específicas para o setor, desenvolvidas a partir da década de 1990, foi de suma importância para o desenvolvimento do setor (CHALITA e SILVA, 2010). No entanto, no que se refere às exportações da cachaça brasileira é necessário considerar aspectos macroeconômicos e da política comercial implementadas durante os governos FHC, Lula e Dilma.

Entende-se por política comercial externa o conjunto de ações por meio das quais os interesses que constituem a agenda comercial de um país, no caso o Brasil, são promovidos diante de outros Estados. Essa política abrange negociações comerciais tanto no âmbito bilateral e regional, quanto multilateral e impactam diretamente os indicadores econômicos de um país (FERNANDES, 2012; OLIVEIRA, 2012).

No que se refere ao governo de Fernando Henrique Cardoso (1994-2002), é importante considerar a política de abertura do mercado externo brasileiro, instituída no início da década de 1990 (pelo governo de Fernando Collor de Mello). Além disso, o contexto macroeconô- 
mico era marcado pela alta inflação, a implementação do Plano Real e uma taxa de câmbio pré-fixada, o que dificultava os ganhos com exportações dada a valorização da moeda. No entanto, a partir de 1994, com o controle das metas de inflação e a conformação às orientações de instituições do comércio internacional, a política cambial brasileira passou a adotar uma taxa de câmbio flutuante (OLIVEIRA, 2012). Nesse sentido, a política comercial externa do país voltou-se ao incentivo às exportações brasileiras, destacando a criação da Agência de Promoção de Exportação (Apex) (RODRIGUES e BENEDICTO, 2009).

Durante o governo de FHC, as exportações passaram a ser reconhecidas como um importante caminho para o desenvolvimento econômico nacional, de modo que diversas políticas voltadas a esse fim foram desenvolvidas (OLIVEIRA e TUROLLA, 2003). A política comercial externa do Brasil nesse período compreendeu estratégias de negociação de acordo com diretrizes da Organização Mundial do Comércio $(\mathrm{OMC})$, acordos regionais na América do Sul e acordos comerciais com países e blocos fora do Mercosul, especialmente Estados Unidos e União Europeia. Em suma, estas ações buscavam articular o binômio autonomia e desenvolvimento no país (OLIVEIRA, 2012). Em agosto de 2001, Fernando Henrique Cardoso empossou o ministro Sérgio Amaral, que instituiu um programa de aumento das exportações de produtos nacionais para novos mercados, fortalecendo e criando relações (RODRIGUES e BENEDICTO, 2009).

Pode-se destacar com Verdi (2006) que a cachaça foi considerada um produto prioritário na pauta de exportação brasileira a partir do 'Projeto de Promoção de Exportações', política desenvolvida pela Agência de Promoção de Exportações (Apex), em 2001. Além disso, o setor também é citado no 'Programa Especial de Exportações' (PEE). Pode-se relacionar tal iniciativa como um dos fatores que influenciaram a promulgação do Decreto no 4.062/2001 que estabelece a cachaça como produto tipicamente brasileiro, como forma de fortalecer a bebida no mercado externo.

Adiante, quando Luiz Inácio Lula da Silva foi eleito presidente, em 2002, a situação macroeconômica do País passava por um momento de estabilização devido à política econômica anterior (RANZI, 2011). Nesse sentido, ainda que o programa de governo de Lula tenha proposto um distanciamento dessas medidas, a política econômica desenvolvida em seu primeiro man- dato foi próxima da anterior. Ou seja, mantiveram-se as metas de inflação, taxa de juros e taxa de câmbio flutuante (OLIVEIRA, 2012). Contudo, os objetivos desta política, sobretudo no segundo mandato apresentaram diferenças significativas. Especialmente após 2006, buscando fomentar a indústria nacional e o consumo por meio das classes baixas, o governo passou a intervir de forma mais recorrente na taxa de câmbio, caracterizando a denominada política cambial de flutuação suja (RANZI, 2011). Estas medidas, juntamente à crise econômica mundial de 2008, influenciaram no desincentivo às exportações em certos setores, embora a balança comercial tenha alcançado números recordes devido às exportações de commodities, especialmente para China e Índia (OLIVEIRA, 2012).

Rodrigues e Benedicto (2009) discutem que a política comercial externa no governo Lula foi pautada no incentivo à manutenção e criação de acordos comerciais e de integração econômica com diferentes nações, sobretudo países asiáticos, africanos e árabes. Apesar de fortalecer relações com os países do Mercosul, procurou-se ampliar o acesso a mercados externos e garantir interesses econômicos de empresas brasileiras com atuação internacional (OLIVEIRA, 2012). Tais direcionamentos estavam relacionados a uma estratégia de afirmação do Brasil como líder continental (CORNETET, 2014).

Comparativamente, de acordo com Costa e Lamarca (2013), os governos de FHC e Lula foram marcados por orientações políticas notadamente opostas em relação a várias áreas de políticas públicas. $\mathrm{O}$ governo Lula, por exemplo, teria sido definido pela tradição nacional-desenvolvimentista, enquanto que a coalizão de FHC era explicitamente favorável à reforma do Estado e a internacionalização da economia brasileira.

Segundo Teixeira e Pinto (2012), as reformas de FHC não proporcionaram o esperado desenvolvimento, na verdade, produziram uma situação de instabilidade macroeconômica permanente e a um padrão de crescimento 'Stop and $G o^{\prime}$. Isso conduziu ao aumento da dívida pública externa e, principalmente, a interna. $\mathrm{O}$ resultado foi a expressiva queda da formação bruta de capital da economia como porcentagem do PIB, entre 1995 e 2002, elevado desemprego e baixas taxas de crescimento, além da deterioração fiscal.

Desse modo, os autores demonstram que, quanto ao desempenho e à dinâmica macroeconômica, os 
resultados (setor externo, nível de atividade, inflação, emprego e renda e finanças públicas) dos dois governos Lula foram melhores do que os de seu antecessor. Entre 2003 e 2010, o Brasil atravessou o maior ciclo de crescimento das últimas três décadas. O PIB cresceu $4,1 \%$ ao ano, quase o dobro do observado entre 1980 e 2002 (2,4\% ao ano). As contas externas da economia brasileira no governo Lula apresentaram resultados muito positivos expressos nos superávits do balanço de pagamentos entre 2003 e 2010 (US\$231,8 bilhões no acumulado). Consoante aos dados relatados aqui pelas pesquisas dos autores citados, é possível perceber também o aumento das exportações da cachaça nos períodos da gestão do governo Lula.

Por fim, durante o governo de Dilma Rousseff, a política econômica se manteve semelhante, em certa medida, à gestão Lula, especialmente nos primeiros anos do mandato. $\mathrm{O}$ tripé macroeconômico conservador foi mantido, a balança comercial permaneceu favorável devido às exportações de commodities; porém, a equipe econômica de Dilma enfrentou dificuldades em relação ao crescimento do PIB, bem como o aumento nos gastos públicos (BRESSER-PEREIRA, 2013).

Conforme Cornetet (2014), a política comercial externa desenvolvida no governo Dilma procurou seguir os mesmos objetivos do governo anterior, especialmente a articulação do desenvolvimento nacional e a diversificação de parceiros comerciais. Nesse sentido, destacam-se os acordos envolvendo o grupo de países emergentes denominado Brics (Brasil, Rússia, Índia, China e África do Sul), embora a diplomacia nesse período tenha ocorrido com menos ativismo e mais limitações de ordem externa se comparadas ao governo anterior. Assim, partindo dessa contextualização teórica, serão tratados na próxima seção os procedimentos metodológicos utilizados na pesquisa.

\section{Metodologia e fonte de dados}

Este trabalho consiste em uma pesquisa de natureza quantitativa e de caráter descritivo. Durante a pesquisa, procurou-se descrever o fluxo de exportações da cachaça brasileira no período de 1997 a 2015, classificando, especificamente, os períodos dos governos 'FHC', 'Lula' e 'Dilma'.

Para tal, foram utilizadas fontes de dados secundárias referentes às exportações da cachaça disponíveis no Sistema de Análises das Informações de Comércio Exterior (AliceWeb 2.0). Tal ferramenta possibilitou o acesso a indicadores do comércio exterior brasileiro agrupados conforme o tipo do produto, país importador, estado exportador etc.

Nesse sentido, foram buscados dados das exportações de cachaça com base em seu no registro da Nomenclatura Comum do Mercosul (NCM), código de oito dígitos adotado pelo governo federal, a partir de 1995, para identificar a natureza dos produtos brasileiros no que se refere ao comércio exterior. No caso da cachaça, o valor na NCM é 2208.40.00, classificada como "Rum e outras aguardentes provenientes da destilação, após fermentação, de produtos da cana-de-açúcar". Esta nomenclatura não distingue a cachaça produzida industrialmente daquela fabricada de forma artesanal, ainda que existam diferenças significativas entre a produção e o fluxo de consumo das duas bebidas (COUTINHO, 2011).

Conforme definido anteriormente, para fins analíticos, o período investigado neste trabalho compreendeu os anos referentes aos governos de Fernando Henrique Cardoso (1994-2002), Luiz Inácio Lula da Silva (2003-2010) e o primeiro mandato de Dilma Rousseff (2011-2015). Entretanto, por uma limitação do sistema AliceWeb, junto à classificação NCM da cachaça, só foi possível realizar a busca a partir de 1997. Tal demarcação, contudo, condiz com o período de implementação das primeiras políticas públicas direcionadas à exportação da bebida (SOUZA e VALLE, 2004).

Os dados coletados foram, então, delimitados, conforme o período estipulado (1997-2015), procurando destacar os países de destino das exportações, bem como os estados exportadores. Além disso, a plataforma AliceWeb 2.0 retorna resultados de três variáveis relacionadas às classificações das transações, a saber: valor monetário exportado (em dólares, US\$), peso (em kg) e quantidade (em litros). Após coletados, os dados foram organizados por meio do Microsoft Excel.

No que se refere à análise, procurou-se inicialmente apresentar a descrição das variáveis considerando a totalidade dos anos e os governos estudados. A análise descritiva, segundo Domingues (2005), refere-se às medidas utilizadas para sumarizar certas características das distribuições de frequência de um conjunto de dados e descrevê-las.

Adiante, com vistas a identificar grupos de países, ou mercados, e classificá-los quanto a seu potencial 
como importador, procedeu-se uma análise de conglomerados, ou clusters. A análise de cluster é uma técnica de análise estatística multivariada cujo objetivo principal é identificar e organizar casos ou objetos em grupos com características semelhantes, classificando-os quanto a variáveis que os representam (ou as variáveis estatísticas do agrupamento). Nesse caso, procura-se entender a população por meio da análise dos grupos que a constituem (MALHOTRA, 2006; HAIR JR et al., 2005).

Dessa forma, procurou-se classificar os países e estados conforme os valores médios (nos períodos analisados) das variáveis independentes: valor monetário (US\$), peso (kg) e quantidade (litros). Para operacionalizar este procedimento foi utilizado o software SPSS.

Tal análise foi realizada conforme o modelo hierárquico, que pressupõe a construção dinâmica de grupos a partir de uma hierarquia estrutural, de modo que a base de dados vai se separando em clusters menores com características semelhantes até que cada observação seja um agrupamento em si mesmo (MALHOTRA, 2006). No que se refere ao procedimento de ligação dos grupos, adotou-se o método de Ward, o mais utilizado neste tipo de técnica, que inicia a formação dos grupos considerando cada caso equivalente a um cluster, existindo, assim, tantos clusters quanto casos que se aglomeram até formar apenas um grupo (MANLY, 2008). Ressalta-se ainda que, para medir a distância entre os casos, foi utilizada a distância euclidiana ao quadrado, medida que calcula o comprimento da hipotenusa de um triângulo retângulo entre os pontos, sem calcular sua raiz quadrada (HAIR JR. et al., 2005).

Assim, uma vez descritos os procedimentos metodológicos, segue-se a apresentação dos resultados e discussões na seção seguinte.

\section{Resultados e discussão}

Apesar de o presente trabalho ter como direcionamento principal a análise das exportações durante os governos FHC, Lula e Dilma, separadamente, faz-se necessário trazer o panorama geral das transações da cachaça entre 1997 e 2015. No período analisado, a bebida foi exportada para 98 países, abrangendo todos os continentes do globo (Figura 1). Observa-se que o principal destino da cachaça nesses anos foram os países europeus (32 nações), seguidos por uma distribuição semelhante entre Ásia (17), África (15), América do Sul (12) e América Central (12). Há de se destacar, contudo, que os oito países importadores localizados na América do Norte representam quase em sua totalidade as nações deste continente.

Na sequência, a Tabela 1 mostra o valor (em US\$), o peso (kg) e a quantidade (litros) das exportações de cachaça de 1997 a 2015, bem como suas respectivas médias e valores totais. Pelos resultados é possível observar uma tendência de valorização na arrecadação

Figura 1. Distribuição de países, em unidades, importadores de cachaça por continente

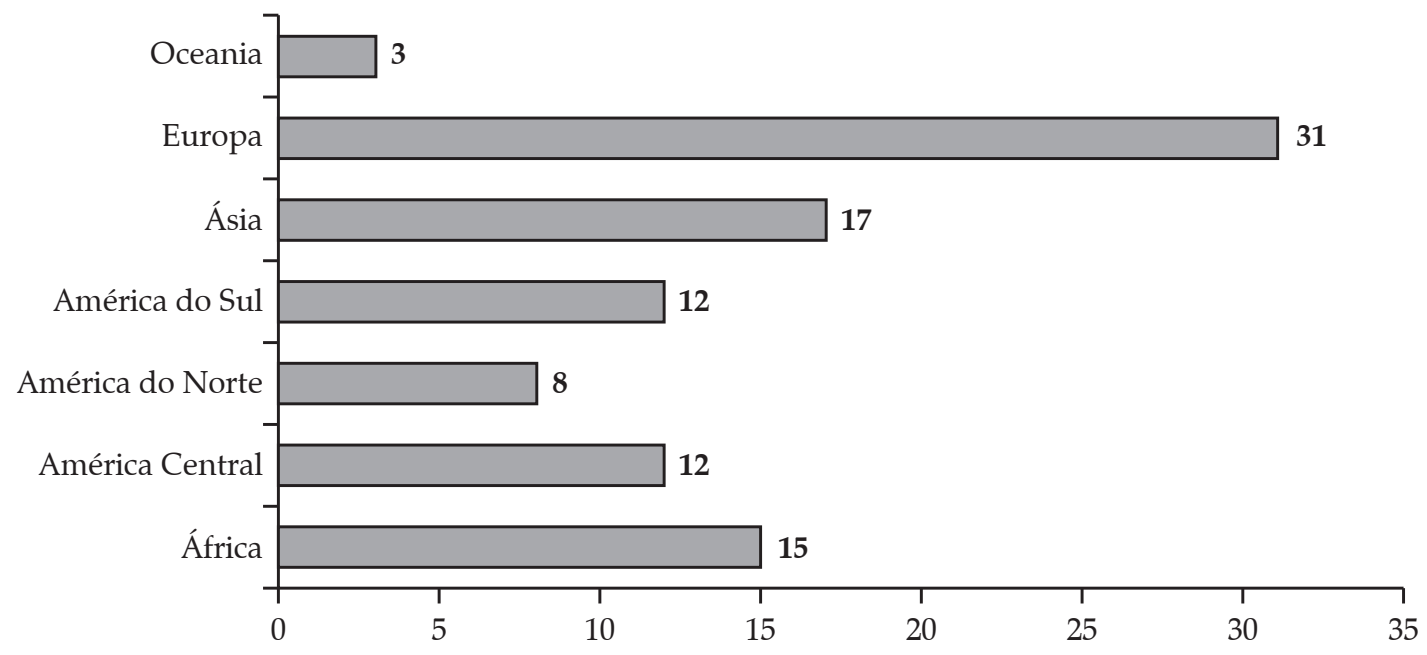

Fonte: Elaborado pelos autores com base nos dados do sistema AliceWeb 2.0. 
Tabela 1. Valor, peso e quantidade exportada de cachaça entre 1997 e 2015 (em milhões)

\begin{tabular}{cccc}
\hline Ano & Valor (milhões de US\$) & Peso (milhões de Kg) & Quantidade (milhões de litros) \\
\hline 1997 & 6,73 & 8,17 & 8,87 \\
1998 & 6,92 & 6,34 & 5,57 \\
1999 & 7,39 & 8,70 & 13,40 \\
2000 & 8,01 & 9,87 & 10,14 \\
2001 & 8,43 & 10,53 & 14,53 \\
2002 & 8,73 & 11,04 & 8,66 \\
2003 & 8,66 & 8,23 & 8,61 \\
2004 & 11,08 & 10,28 & 10,32 \\
2005 & 12,49 & 10,86 & 11,27 \\
2006 & 14,32 & 11,74 & 9,04 \\
2007 & 13,80 & 9,01 & 11,08 \\
2008 & 16,37 & 11,28 & 10,80 \\
2009 & 15,52 & 11,11 & 10,44 \\
2010 & 15,95 & 10,61 & 9,80 \\
2011 & 17,26 & 9,99 & 8,12 \\
2012 & 14,88 & 8,08 & 9,21 \\
2013 & 16,53 & 9,03 & 10,18 \\
2014 & 18,15 & 9,43 & 7,77 \\
2015 & 13,37 & 7,71 & 209,81 \\
Total & 258,13 & 202,98 & 9,75 \\
Média & 11,71 & 9,45 & \\
\hline
\end{tabular}

Fonte: Elaborado pelos autores com base nos dados do sistema AliceWeb 2.0.

com as transações, com destaque para 2014, cujo montante negociado foi de US\$ 18.151.544,00 (sobretudo pela grande quantidade importada por Alemanha, Estados Unidos, Portugal e Paraguai). No entanto, tal tendência de crescimento não acompanha a quantidade, em litros, exportada, que apresentou ampla variação de valores no período. São destacados, com relação à quantidade, os anos 2000 e 2002, com os maiores montantes exportados, 13.399 .563 e 14.529 .074 litros, respectivamente. Da mesma forma, percebe-se queda nos números exportados em 2015 em comparação com a série histórica que apresentava crescimento.

Adiante, considerando os estados exportadores, de 1997 a 2015, 21 unidades federativas (UF) negociaram sua produção de cachaça para o mercado externo, ou seja, a maioria dos estados brasileiros exportou a bebida nesse período. Desta maneira, a Tabela 2 evidencia o valor (US\$), o peso (kg) e quantidade (litros) exportada, por UF, bem como o índice de concentração de cada estado diante da quantidade total de cachaça comercializada internacionalmente. Observa-se que os estados de São Paulo, Pernambuco, Rio de Janeiro, Paraná e Minas Gerais são os maiores exportadores do País. Ademais, os estados de São Paulo e Pernambuco são responsáveis por $57,39 \%$ da quantidade total exportada no País. Nestes dois estados, são fabricadas duas das principais marcas de cachaça industrial do Brasil.

Especificamente no governo Fernando Henrique Cardoso, o percentual da quantidade de exportações, por estado, é evidenciado conforme a Figura 2. Entre 1997 e 2002 foram comercializados 60.668 .909 de litros do destilado, produzidos em 17 estados. Observa-se que o estado de São Paulo foi o maior exportador de cachaça do País, seguido de Pernambuco e Paraná. Os três estados foram responsáveis por 80,99\% das exportações no período. 
Tabela 2. Valor, peso, quantidade e índice de concentração da quantidade total exportada de cachaça, por estado, entre 1997 e 2015

\begin{tabular}{|c|c|c|c|c|}
\hline Descrição da UF & Total US\$* & Total $\mathrm{Kg}^{* *}$ & Total Qtd ${ }^{* * *}$ & \% Qtd no País**** \\
\hline São Paulo & 111.728 .912 & 74.007 .605 & 80.529 .483 & $38,381 \%$ \\
\hline Pernambuco & 27.275 .130 & 37.942 .351 & 39.876 .841 & $19,006 \%$ \\
\hline Rio de Janeiro & 24.638 .195 & 13.386 .667 & 12.918 .158 & $6,157 \%$ \\
\hline Paraná & 17.534 .663 & 23.777.214 & 23.233 .372 & $11,073 \%$ \\
\hline Minas Gerais & 16.024 .758 & 4.611 .235 & 4.417 .248 & $2,105 \%$ \\
\hline Ceará & 15.955 .061 & 5.870 .886 & 5.922 .027 & $2,823 \%$ \\
\hline Rio Grande do Sul & 12.057 .719 & 17.133 .504 & $14.433 .876,2$ & $6,879 \%$ \\
\hline Mato Grosso do Sul & 2.828 .602 & 2.886 .234 & 2.822 .827 & $1,345 \%$ \\
\hline Santa Catarina & 1.603 .918 & 1.113 .586 & 893.453 & $0,426 \%$ \\
\hline Bahia & 835.658 & 182.808 & 163.091 & $0,078 \%$ \\
\hline Goiás & 626.120 & 308.803 & 292.771 & $0,140 \%$ \\
\hline Paraíba & 234.404 & 152.579 & 85.111 & $0,041 \%$ \\
\hline Pará & 196.292 & 58.068 & 8.150 & $0,004 \%$ \\
\hline Espírito Santo & 53.227 & 43.794 & 3.7292 & $0,018 \%$ \\
\hline Sergipe & 51.544 & 47.762 & 4.2843 & $0,020 \%$ \\
\hline Mato Grosso & 37.528 & 14.919 & 2.0409 & $0,010 \%$ \\
\hline Roraima & 13.508 & 15.300 & 1.4443 & $0,007 \%$ \\
\hline Rondônia & 9.105 & 7.510 & 5.472 & $0,003 \%$ \\
\hline Amazonas & 9.013 & 7.303 & 12.840 & $0,006 \%$ \\
\hline Acre & 4.474 & 5.020 & 3.840 & $0,002 \%$ \\
\hline Rio Grande do Norte & 195 & 176 & 176 & $0,000 \%$ \\
\hline
\end{tabular}

* Valor total, em dólares, de exportações de cachaça; ** Valor total, em quilogramas, de exportações de cachaça; *** Quantidade total, em litros, de exportações de cachaça; Participação percentual da Unidade Federativa na quantidade total, em litros, de exportações de cachaça.

Fonte: Elaborado pelos autores com base nos dados do sistema AliceWeb 2.0.

Figura 2. Percentual da quantidade, em litros, exportada de cachaça por estado durante o governo FHC (1997-2002)

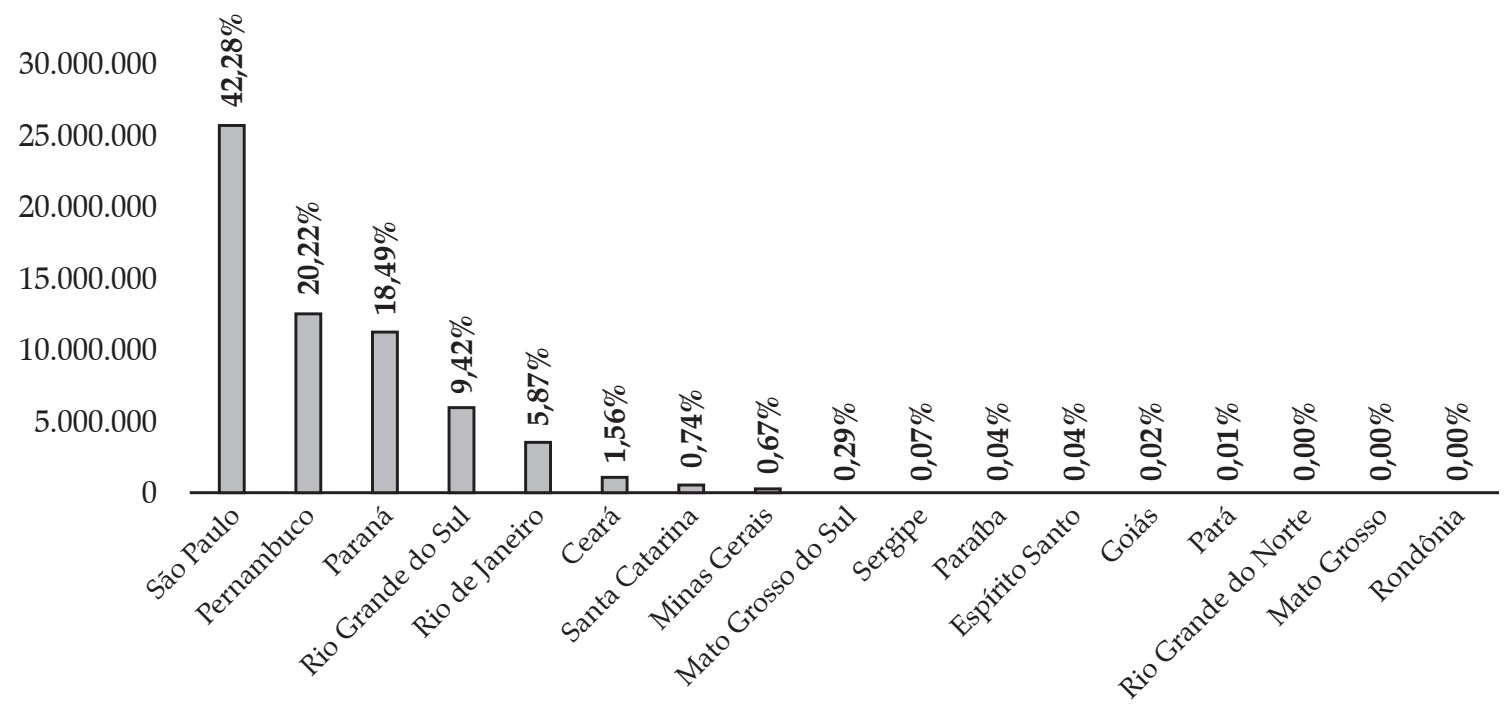

Fonte: Elaborado pelos autores com base nos dados do sistema Alice Web 2.0. 
Por sua vez, a Figura 3 apresenta o percentual da quantidade, em litros, exportada pelos estados brasileiros durante o governo Lula (2003-2010). Nesse período foram exportados 79.996 .577 litros da bebida, produzidos também em 17 estados, embora algumas unidades federativas tenham variado. Da mesma forma, os estados de São Paulo, Pernambuco e Paraná se destacam entre os demais, tendo o primeiro estado exportado quase metade do total. O estado de Minas Gerais apresenta um grande salto no percentual da quantidade exportada quando comparados os anos de 1997 a 2003, ou seja, de $0,67 \%$ para $2,55 \%$.

Finalmente, a Figura 4 mostra o percentual da quantidade de cachaça exportada pelas unida-

Figura 3. Percentual da quantidade, em litros, exportada de cachaça por estado durante o governo Lula (2003-2010)

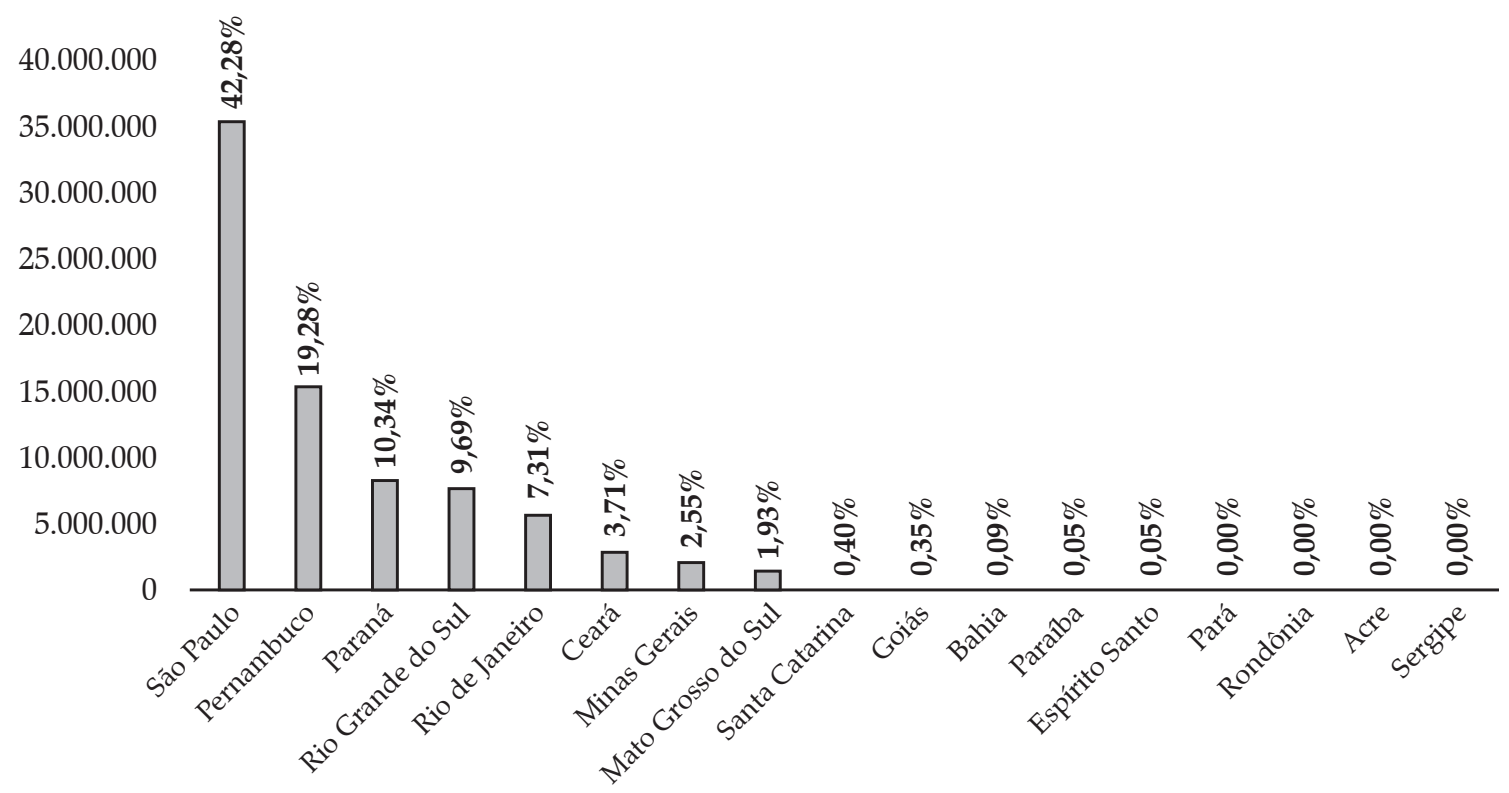

Fonte: Elaborado pelos autores com base nos dados do sistema Alice Web 2.0.

Figura 4. Percentual da quantidade, em litros, exportada de cachaça por estado durante o governo Dilma Rousseff (2011-2015)

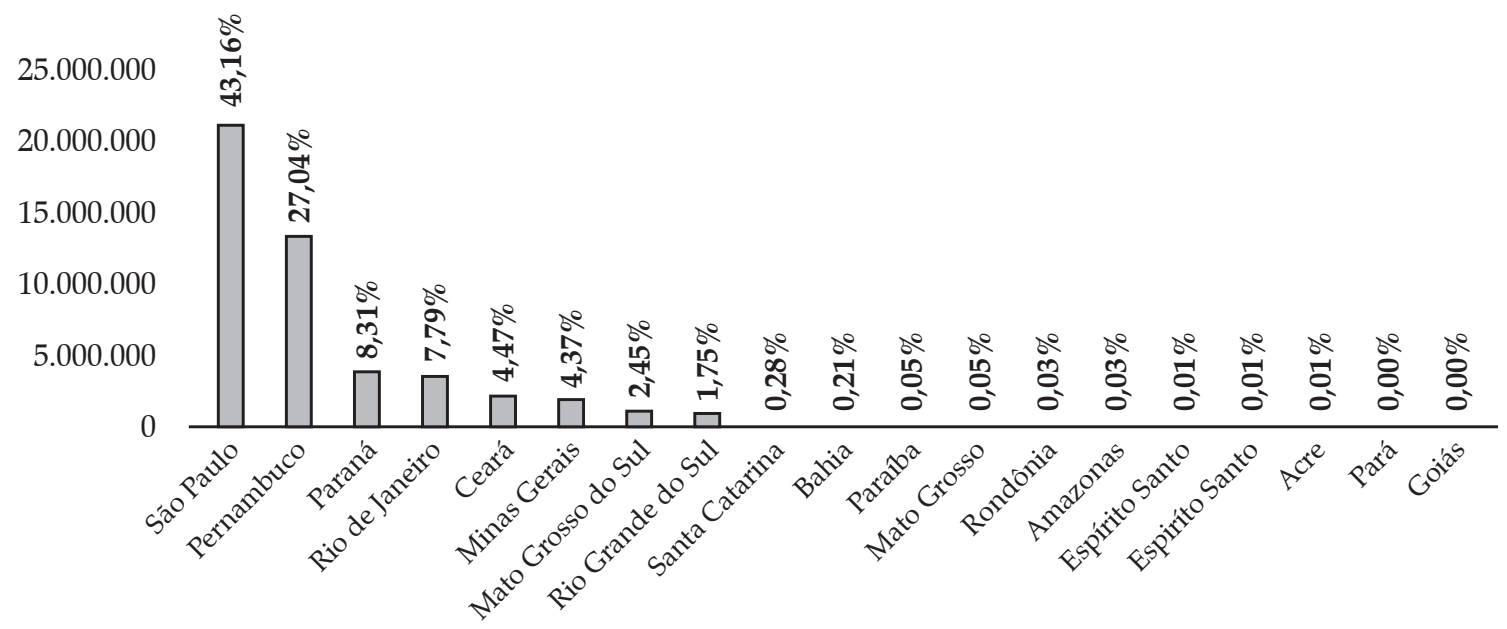

Fonte: Elaborado pelos autores com base nos dados do sistema Alice Web 2.0. 
des federativas brasileiras durante o governo Dilma Rousseff (2011-2015). Foram 45.078.166 litros, distribuídos entre 19 estados. No entanto, tal como nos períodos anteriores, São Paulo, Pernambuco e Paraná representam os maiores exportadores. Minas Gerais mais uma vez aumenta sua participação no quadro geral, ao passo que o Rio Grande do Sul tem diminuído a quantidade exportada quando comparado a outros estados e outros períodos. Durante o governo Dilma, outros estados, como Roraima e Bahia, passaram a figurar entre os exportadores.

Adiante, uma vez apresentado o fluxo descritivo das exportações de cachaça no Brasil entre 1997 e 2015, foram identificados os grupos de países importadores da bebida nos períodos analisados por meio da análise de clusters. Dessa forma, partindo da distinção entre os governos, foram formulados agrupamentos de países que representam os principais mercados compradores de cachaça brasileira.

No que se refere ao período de 1997 a 2002, relativo ao governo de Fernando Henrique Cardoso, foi possível identificar que o Brasil exportou cachaça para 49 países, dentre os quais foram formados três grupos, conforme o Quadro 1. Evidencia-se: o grupo de países com alto nível de importação (grupo 1), formado por Alemanha e Paraguai; o grupo de países com nível intermediário de importações (grupo 2), constituído por Bélgica, Bolívia, Chile, Equador, Espanha, Estados Unidos, França, Itália, Holanda, Portugal e Uruguai; e um terceiro grupo de países com baixo índice de importação, formado por 36 países. Destaca-se que os estados que mais exportaram para os países do pri- meiro grupo foram: São Paulo, Rio de Janeiro, Paraná e Pernambuco. Além disso, os clusters formados mostram que os principais países importadores nesse período, nos agrupamentos 1 e 2 , se dividem pelos continentes europeu, sul-americano e norte-americano (representado unicamente pelos Estados Unidos).

$\mathrm{Na}$ sequência, considerou-se o governo Lula, de 2003 a 2010, para a construção de agrupamentos de mercados importadores. No período, a bebida foi exportada para 86 países, de modo que foram construídos 4 grupos (Quadro 2), sendo o primeiro deles formado por um único país, a Alemanha, destacando-se dos demais como o principal importador da bebida no período. Os outros clusters agrupam países conforme sua representação no mercado externo do destilado. Assim, o grupo 2 refere-se a nações com alto nível de importações, formado por Estados Unidos, Paraguai, Portugal e Uruguai. O grupo 3 compreende nações com nível intermediário em importações, constituído por 11 países: Angola, Argentina, Bélgica, Bolívia, Chile, Espanha, França, Itália, Holanda, Reino Unido e Suíça. Por fim, o grupo 4 representa aqueles com baixo nível de importações de cachaça, sendo formado por 70 países. Observa-se que nos grupos dos países com níveis alto e intermediário de importações houve pouca variação de nações quando comparados aos clusters referentes ao governo FHC.

Por fim, foram construídos os agrupamentos referentes aos países importadores de cachaça durante o governo Dilma Rousseff, conforme mostrado no Quadro 3. Dessa forma, observa-se que a bebida foi exportada para 73 nações no período de 2011 a 2015,

Quadro 1. Caracterização dos clusters para destinos de exportação de cachaça no período 1997 a 2002

\begin{tabular}{|c|c|c|c|c|c|}
\hline \multicolumn{2}{|r|}{ Grupo } & Média & Desvio Padrão & $\mathbf{N}$ & Destinos \\
\hline 1 & $\begin{array}{c}\text { Valor (U\$) } \\
\text { Peso (kg) } \\
\text { Qtd (litros) } \\
\end{array}$ & $\begin{array}{l}1.699 .561,00 \\
2.501 .418,50 \\
3.093 .318,67 \\
\end{array}$ & $\begin{array}{c}39.652,93 \\
473.949,73 \\
943.046,16 \\
\end{array}$ & 2 & Alemanha e Paraguai \\
\hline 2 & $\begin{array}{l}\text { Valor (U\$) } \\
\text { Peso (kg) } \\
\text { Qtd (litros) }\end{array}$ & $\begin{array}{l}341.334,56 \\
320.628,31 \\
307.399,10\end{array}$ & $\begin{array}{l}185.714,43 \\
321.176,02 \\
226.843,73\end{array}$ & 11 & $\begin{array}{l}\text { Bélgica; Bolívia; Chile; Equador; Espanha; Estados } \\
\text { Unidos; França; Itália; Holanda; Portugal; Uruguai }\end{array}$ \\
\hline 3 & $\begin{array}{l}\text { Valor (U\$) } \\
\text { Peso (kg) } \\
\text { Qtd (litros) }\end{array}$ & $\begin{array}{l}18.113,15 \\
12.049,68 \\
13.133,91\end{array}$ & $\begin{array}{l}33.172,10 \\
22.315,17 \\
26.922,81\end{array}$ & 36 & $\begin{array}{l}\text { Angola; Antilhas Holandesas; Argentina; Aruba; } \\
\text { Austrália; Áustria; Cabo Verde; Canadá; Ilhas Cayman; } \\
\text { China; Costa Rica; Dinamarca; Finlândia; Grécia; } \\
\text { Guatemala; Hong Kong; Israel; Iugoslávia; Japão; } \\
\text { Jordânia; Malásia; Marrocos; Nova Zelândia; Panamá; } \\
\text { Peru; Porto Rico; Reino Unido; Rússia; Suécia; Suíça; } \\
\text { Taiwan; República Tcheca; Trinidad e Tobago; Venezuela; } \\
\text { Ilhas Virgens; }\end{array}$ \\
\hline
\end{tabular}

Fonte: Elaborado pelos autores com base nos dados do sistema AliceWeb 2.0. 
destacando que alguns países passaram a figurar na lista pela primeira vez, tais como Filipinas, Letônia, Luxemburgo, Vietnã e a República Democrática do Congo. Assim como na análise anterior, foram formados quatro grupos, sendo o primeiro constituído novamente por um único país, Alemanha, maior mercado consumidor internacional da bebida. O grupo 2 representa os países com alto nível de importações e é for- mado por Estados Unidos, França, Paraguai e Portugal (evidenciando um aumento na representatividade da França como consumidora de cachaça). Por sua vez, o grupo 3 é formado por países com nível de importação intermediários: Angola, Argentina, Bélgica, Bolívia, Chile, Espanha, Itália, Holanda, Reino Unido, Suíça e Uruguai. Finalmente, o grupo 4 é constituído pelos 57 países restantes, com baixo nível de importações.

Quadro 2. Caracterização dos clusters para destinos de exportação de cachaça do período 2003 a 2010

\begin{tabular}{|c|c|c|c|c|c|}
\hline \multicolumn{2}{|r|}{ Grupo } & Média & Desv. Padrão & $\mathbf{N}$ & Destinos \\
\hline 1 & $\begin{array}{c}\text { Valor (U\$) } \\
\text { Peso (kg) } \\
\text { Qtd (litros) } \\
\end{array}$ & $\begin{array}{l}2.341 .219,13 \\
2.846 .557,63 \\
2.962 .796,75\end{array}$ & - & 1 & Alemanha \\
\hline 2 & $\begin{array}{c}\text { Valor (U\$) } \\
\text { Peso (kg) } \\
\text { Qtd (litros) }\end{array}$ & $\begin{array}{c}1.137 .138,44 \\
929.180,36 \\
868.922,22 \\
\end{array}$ & $\begin{array}{l}421.684,02 \\
206.402,40 \\
209.917,95 \\
\end{array}$ & 4 & Estados Unidos; Paraguai; Portugal; Uruguai. \\
\hline 3 & $\begin{array}{c}\text { Valor (U\$) } \\
\text { Peso (kg) } \\
\text { Qtd (litros) }\end{array}$ & $\begin{array}{l}454.459,21 \\
283.459,00 \\
266.249,17\end{array}$ & $\begin{array}{l}193.346,18 \\
97.816,582 \\
90.043,556\end{array}$ & 11 & $\begin{array}{l}\text { Angola; Argentina; Bélgica; Bolívia; Chile; Espanha; França; } \\
\text { Itália; Holanda; Reino Unido; Suíça. }\end{array}$ \\
\hline 4 & $\begin{array}{c}\text { Valor (U\$) } \\
\text { Peso (kg) } \\
\text { Qtd (litros) }\end{array}$ & $\begin{array}{l}23.556,36 \\
10.537,73 \\
10.113,23\end{array}$ & $\begin{array}{l}31.945,65 \\
15.584,14 \\
15.398,81\end{array}$ & 70 & $\begin{array}{l}\text { África do Sul; Andorra; Angola; Antígua e Barbuda; Antilhas } \\
\text { Holandesas; Aruba; Austrália; Áustria; Bahamas; Bermudas; } \\
\text { Bulgária; Cabo Verde; Canadá; Camarões; Ilhas Cayman; China; } \\
\text { Cingapura; Coréia do Sul; Costa Rica; Croácia; Dinamarca; } \\
\text { El Salvador; Emirados Árabes Unidos; Eslovênia; Estônia; } \\
\text { Finlândia; Gana; Grécia; Guatemala; Guiana; Guiana Francesa; } \\
\text { Guiné Equatorial; Hong Kong; Hungria; Índia; Irlanda; Japão; } \\
\text { Jordânia; Líbano, Macau; Malásia; Marrocos; Martínica; } \\
\text { México; Moçambique; Mônaco; Namíbia; Nicarágua; Noruega; } \\
\text { Nova Zelândia; Panamá; Peru; Polinésia Francesa; Polônia; } \\
\text { Porto Rico; Quênia; República Dominicana; Romênia; Rússia; } \\
\text { Senegal; Suécia; Suriname; Tailândia; Taiwan; República } \\
\text { Tcheca; Togo; Turquia; Venezuela. }\end{array}$ \\
\hline
\end{tabular}

Fonte: Elaborado pelos autores com base nos dados do sistema AliceWeb 2.0.

Quadro 3. Caracterização dos Cclusters para destinos de exportação de cachaça do período 2011 a 2015

\begin{tabular}{|c|c|c|c|c|c|}
\hline \multicolumn{2}{|r|}{ Grupo } & Média & Desv. Padrão & $\mathbf{N}$ & Destinos \\
\hline 1 & $\begin{array}{l}\text { Valor (U\$) } \\
\text { Peso (kg) } \\
\text { Qtd (litros) }\end{array}$ & $\begin{array}{l}2.766 .769,80 \\
2.302 .113,00 \\
2.547 .250,60\end{array}$ & $\begin{array}{l}- \\
- \\
-\end{array}$ & 1 & Alemanha \\
\hline 2 & $\begin{array}{c}\text { Valor (U\$) } \\
\text { Peso (kg) } \\
\text { Qtd (litros) } \\
\end{array}$ & $\begin{array}{c}1.505 .721,70 \\
781.906,15 \\
764.036,20 \\
\end{array}$ & $\begin{array}{l}401.731,48 \\
202.153,65 \\
212.251,01 \\
\end{array}$ & 4 & Estados Unidos; França; Paraguai; Portugal \\
\hline 3 & $\begin{array}{l}\text { Valor (U\$) } \\
\text { Peso (kg) } \\
\text { Qtd (litros) }\end{array}$ & $\begin{array}{l}503.763,78 \\
253.856,07 \\
258.366,92\end{array}$ & $\begin{array}{l}215.035,79 \\
114.722,04 \\
116.347,09\end{array}$ & 11 & $\begin{array}{l}\text { Angola; Argentina; Bélgica; Bolívia; Chile; Espanha; Itália; } \\
\text { Holanda; Reino Unido; Suíça; Uruguai; }\end{array}$ \\
\hline 4 & $\begin{array}{c}\text { Valor (U\$) } \\
\text { Peso (kg) } \\
\text { Qtd (litros) }\end{array}$ & $\begin{array}{l}29.985,14 \\
10.945,62 \\
10.000,82\end{array}$ & $\begin{array}{l}44.528,36 \\
18.057,83 \\
15.107,42\end{array}$ & 57 & $\begin{array}{l}\text { África do Sul; Austrália; Áustria; Bahamas; Cabo Verde; Canadá; } \\
\text { Cayman, Ilhas; China; Chipre; Cingapura; Colômbia; Congo, } \\
\text { República Democrática; Coreia do Sul; Costa do Marfim; } \\
\text { Costa Rica; Croácia; Dinamarca; El Salvador; Emirados Árabes } \\
\text { Unidos; Equador; Estônia; Filipinas; Gabão; Grécia; Guiana; } \\
\text { Guiana Francesa; Guiné Equatorial; Haiti; Hong Kong; Îndia; } \\
\text { Irlanda; Israel; Japão; Letônia; Líbano; Luxemburgo; Malásia; } \\
\text { Marrocos; México; Noruega; Nova Zelândia; Panamá; Peru; } \\
\text { Polônia; Porto Rico; República Dominicana; Rússia; Senegal; } \\
\text { Suécia; Suriname; Tailândia; Taiwan (Formosa); Tcheca, } \\
\text { República; Trinidad e Tobago; Turquia; Venezuela; Vietnã; }\end{array}$ \\
\hline
\end{tabular}

Fonte: Elaborado pelos autores com base nos dados do sistema AliceWeb 2.0. 
Por meio dos resultados apresentados, é possível afirmar que a cachaça brasileira tem sido exportada para todos os continentes, com destaque para América do Sul, América do Norte e Europa. Este padrão tem aumentado no decorrer dos anos, evidenciando, que o mercado externo do destilado tende a se expandir cada vez mais, uma vez que a cada período analisado o número de novos países importadores aumentou.

Além disso, percebe-se um aumento contínuo no valor, em dólares, das exportações de 1997 a 2014, embora esse crescimento não acompanhe a quantidade, em litros, exportada, que apresentou grande oscilação no mesmo período. Esse fenômeno pode estar relacionado a variações nos preços de venda da bebida que, no geral, tenderam a aumentar independentemente da quantidade exportada. A queda nos valores exportados em 2015 deve ser monitorada com cuidado, a fim de observar se o fenômeno tem relação direta com a crise econômica que o país passou.

De forma geral, dentre os mercados importadores de cachaça, construidos com base na análise de agrupamentos dos períodos, destaca-se a Alemanha como o principal consumidor externo da bebida. Porém, além da Alemanha, outros países merecem destaque, tais como Estados Unidos, Paraguai e França. Nesse sentido, pode-se destacar que o market share da cachaça nesses países foi construido ao longo dos anos de forma sustentável. Além disso, apesar da ampla presença de países africanos importando a bebida, sobretudo durante o governo Lula, apenas Angola se destaca como mercado de bom potencial de consumo do destilado.

Considerando os impactos das políticas públicas e legislações relacionadas à cachaça no período analisado, observa-se que a partir de 2001, quando foi publi-

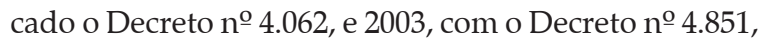
o valor das exportações, em todas as variáveis analisadas, cresceu substancialmente, sobretudo a partir de 2004. Possivelmente este é um efeito de tais medidas que passaram a normatizar as características da bebida e a institucionalizou como uma indicação geográfica do País. Na mesma direção, outra medida que pode ter influenciado diretamente no fortalecimento das relações de exportações foi a criação da Câmara Setorial da Cadeia Produtiva da Cachaça, em 2005, que intermedia demandas de produtores e outras instituições a fim de proporcionar maior governança na cadeia produtiva da bebida.
Ao se considerar o período do governo FHC, observa-se que as exportações da cachaça apresentaram crescimento, ainda que não tenha sido possível observar uma comparação com um período anterior devido a limitações da base de dados. Contudo, reconhece-se que as políticas e dispositivos legais voltados à cadeia produtiva da cachaça implementados no governo FHC podem ter sido fundamentais para formar a base de uma política de exportações do destilado. Assim, pela discussão, observa-se que tais programas e ações formuladas no governo FHC, tais como o PBDAC e os decretos de normatização da bebida, representaram o crescimento nas exportações durante o primeiro mandato do governo Lula. Também é possível creditar o aumento nas exportações do destilado a partir de 2004 devido ao período de crescimento econômico que marcou a gestão do presidente Luís Inácio Lula da Silva (TEIXEIRA e PINTO, 2012).

Apesar das exportações compreenderem todos os continentes do globo, durante o governo de FHC as principais nações consumidoras da bebida localizavam-se na Europa e na América do Sul. Tal relação mais próxima com os países da América do Sul está relacionada aos acordos comerciais firmados com estes Estados, em destaque o Mercado Comum do Sul (Mercosul), aliança de livre comércio entre Brasil, Argentina, Paraguai, Uruguai e Venezuela (BENETET, 2014).

Por sua vez, no governo Lula observa-se um retrato da política comercial externa do país no período que procurou reforçar laços comerciais com mercados construídos no governo FHC e expandir as negociações com outras nações, tais como países asiáticos e africanos. Cavalcante e Lima (2013) explicam que, apesar de ser objetivo do então governo Lula ampliar as relações comerciais com a América do Sul por meio de tratados de livre comércio, houve avanço significativo também com relação à África. Segundo os autores, em oito anos de governo, Lula viajou ao continente africano 12 vezes e visitaria um total de 23 países desta região. Essas ações resultaram em um aumento do comércio de US\$ 5 bilhões em 2002 para US\$ 26 bilhões em 2008, assim como do comércio entre o Brasil e o Oriente Médio, que triplicou em cinco anos e alcançou US\$ 20 bilhões em 2008. Com relação à Ásia, Cavalcante e Lima (2013) também destacam o estreitamento, no âmbito dos Brics, das relações com a China e a Índia. 
Esse padrão de expansão de parceiros comerciais também permaneceu no governo Dilma Rousseff. Todavia, não foi possível perceber um alto nível de exportações para países que compõem um dos símbolos da política externa brasileira nesse período: os Estados que constituem os Brics.

Com relação ao governo Dilma, destaca-se que o tratado firmado com os Estados Unidos em 2013, reconhecendo a cachaça como produto de exclusividade do Brasil, ainda não apontou aumento das exportações do destilado para aquele país. Entretanto, os Estados Unidos figuraram entre as principais nações importadoras de cachaça durante todo o período analisado.

De modo geral, é possível relacionar o perfil das exportações de cachaça aos aspectos macroeconômicos característicos dos governos analisados, sobretudo no que se refere à implementação das taxas de câmbio flutuante, que incentivaram as exportações. Da mesma forma, o período crescimento econômico do País propiciou melhores estruturas para as exportações na indústria da cachaça no comércio internacional. Entretanto, observa-se que as características do comércio internacional de cachaça são melhor explicadas a partir das políticas específicas do setor, desenvolvidas tanto pela ação do Estado quanto de produtores.

Por fim, no que se refere aos números no mercado externo, é importante ressaltar que quando se considera o potencial estimado de produção anual da bebida, as exportações representam uma pequena fração. Conforme o Ibrac (2016), produz-se aproximadamente 800 milhões de litros de cachaça por safra, seja industrial ou artesanal. A Tabela 1 evidencia que o valor médio de exportações entre 1997 e 2015 foi de 9,75 milhões de litros/safra. Assim, apesar de estar inserida em diferentes países do globo, as exportações da cachaça representam aproximadamente 1,22\%.

Ou seja, estes resultados mostram como ainda são necessárias mais medidas que influenciem as exportações da bebida. Dentre os entraves ao comércio exterior da cachaça, destaca-se o alto índice de informalidade e a dificuldade, por parte dos produtores, em atender a normas e padrões de qualidade exigidos por outros países para a realização das trocas comerciais. Nesse sentido, o Estado tem procurado, a partir de 2005, incentivar fabricantes de cachaça a se conformarem aos padrões técnicos exigidos. Estas medidas são realizadas por meio de cursos, programas de certificação, fiscalizações, dentre outros (CHALITA e SILVA,
2010). Entretanto, as ações do Estado também refletem no índice de informalidade. Conforme Daniel (2016), a principal barreira à formalização dos produtores de cachaça, sobretudo os pequenos produtores, é a alta carga tributária incidida sobre o setor, que em alguns casos pode chegar a $60 \%$ do faturamento.

Nessa direção, a partir dos resultados, observa-se que Minas Gerais, estado historicamente reconhecido pela existência de milhares de alambiques que produzem a cachaça artesanal, representa uma pequena parcela das exportações mundiais. Esse dado chama a atenção também tendo em vista que várias iniciativas sobre a legislação e a regulamentação (INDI, 1982; AMPAQ, 1988) tenham surgido nesse estado.

Portanto, apesar de os dados não diferenciarem a cachaça artesanal da cachaça produzida industrialmente, é possível inferir que a maior parte das exportações da bebida refere-se à cachaça industrial, ainda que estados como Rio Grande do Sul, Paraná e Rio de Janeiro sejam caracterizados pela produção artesanal em alambiques. Tal conclusão também está relacionada à grande participação de estados de São Paulo, Pernambuco e Ceará nos números, uma vez que, nesses estados, estão localizadas as principais indústrias de cachaça do Brasil (SILVA, 2009).

\section{Considerações finais}

Neste trabalho, foi possível investigar e descrever o fluxo das exportações de cachaça, destacando os períodos dos governos de Fernando Henrique Cardoso (1994-2002), Luiz Inácio Lula da Silva (20032010) e Dilma Rousseff (2011-2015). Desta forma, foram analisados dados estatísticos fornecidos pelo sistema AliceWeb 2.0 e procedeu-se a análise descritiva das variáveis, bem como uma análise de clusters com vistas a formar grupos de países importadores da bebida, de modo a caracterizar os principais mercados internacionais para o destilado.

Os grupos formados neste trabalho evidenciam que embora a cachaça seja comercializada em países de todos os continentes, os maiores consumidores estão concentrados na Europa, América do Sul e América do Norte. A Alemanha destaca-se como o maior consumidor da bebida, representando um market share sustentável nas negociações. No entanto, países como França, Paraguai, Estados Unidos e Angola também são 
alternativas importantes para o comércio do destilado. De qualquer modo, é necessário considerar outros países desses principais continentes, sobretudo a partir do estudo das relações que caracterizam o predomínio das exportações nas nações dos grupos de grande potencial importador.

Observou-se que o fluxo das exportações de cachaça no Brasil está relacionado com a atuação do Estado no sentido da criação de políticas e dispositivos legais voltados à promoção e valorização da bebida ao mercado externo, sobretudo os Decretos no 4.062/2001 e no $4.851 / 2003$, bem como a criação da Câmara Setorial da Cadeia Produtiva da Cachaça, em 2005. Nos períodos analisados, evidenciamos um aumento nas exportações de cachaça, sendo a bebida negociada em 98 países (com destaque para a Alemanha), aumentando o faturamento dos produtores de 21 estados brasileiros, especialmente os de São Paulo, Pernambuco, Rio de Janeiro, Paraná e Minas Gerais.

No entanto, é importante ressaltar que o Estado também influencia no acirramento de um dos principais gargalos na produção da cachaça brasileira: a intensa carga tributária que desestimula a produção e a exportação do destilado, especialmente da cachaça artesanal (IBRAC, 2016; SILVA, 2009). Portanto, entende-se que a institucionalização de mecanismos de política tributária específicos a este setor podem apresentar avanços e melhorias nos números das transações de cachaça para o mercado externo. Iniciativas nesta direção têm sido discutidas amplamente por produtores associados e outras organizações junto aos governos federal e estadual.

Além disso, a média, em litros, de cachaça exportada mostra como apenas uma pequena quantidade da produção total do País é destinada ao mercado internacional. Este resultado contraria uma série de previsões elaboradas por atores da cadeia no período de criação das políticas públicas e legislações no final da década de 1990 (COUTINHO, 2001; VERDI, 2006). Desta forma, os resultados discutidos neste artigo podem contribuir como parâmetro para a avaliação destas políticas e das atividades desenvolvidas em torno do setor, sobretudo no âmbito do Estado como promotor da política comercial de incentivo às exportações.

De modo geral, em termos econômicos, este trabalho evidencia que o perfil das exportações de cachaça no Brasil está relacionado a traços da política comercial externa desenvolvida pelos governos FHC, Lula e Dilma. No entanto, os resultados apontam que as características do comércio internacional deste destilado são melhor explicadas pelas políticas de fomento e incentivo às exportações desenvolvidas pelo Estado em parceria com produtores e instituições de pesquisa.

Como limitações deste estudo, pode-se destacar a impossibilidade de trabalhar-se com dados específicos quanto à distinção entre a cachaça artesanal e industrial e da obtenção de dados anteriores ao ano de 1997. Outra limitação deve-se ao não detalhamento das unidades federativas quanto às suas políticas estaduais para a produção de cachaça, o que também pode influenciar no resultado de suas operações.

Assim, propõe-se que pesquisas futuras procurem: i) compreender a atuação de outros entes do pacto federativo em termos da formulação de políticas destinadas à cadeia produtiva da cachaça e seus impactos nas exportações do destilado; ii) estabelecer algum tipo de discriminação das exportações nos dois principais subsistemas de produção de cachaça: artesanal e industrial; iii) compreender e descrever as estratégias desenvolvidas pelas organizações para a inserção de seu produto no mercado externo; dentre outras lacunas que este estudo não se propôs a investigar.

Por fim, a partir deste artigo, sugere-se que os atores envolvidos na cadeia produtiva da cachaça, incluindo agentes governamentais, considerem o panorama das exportações do destilado apresentado nesta pesquisa. Este panorama caracteriza a cachaça como uma bebida com potencial de consumo em países distribuídos em todos os continentes. Todavia, ressalta-se a concentração das transações em certos mercados, a baixa representatividade das exportações frente ao total de cachaça produzido no país e o predomínio da comercialização da cachaça industrial no mercado externo. Reconhecendo que este destilado é um produto genuinamente brasileiro, são necessários maiores esforços para a internacionalização das organizações e maior inserção do destilado no comércio exterior. Como evidenciou-se neste trabalho, o Estado tem papel determinante nesta configuração. Sendo assim, a partir de dispositivos normativos e deliberativos, como a Câmara Setorial da Cachaça, sugere-se uma política orientada ao reajuste da carga tributária e incentivos fiscais às exportações, assistência aos produtores, e investimento na promoção e ressignificação da imagem da cachaça, destacando sua sofisticação e identidade próprias do Brasil e de seus fabricantes. 
Conforme Chalita e Silva (2010) argumentam, o investimento na imagem da cachaça como bebida de valor agregado é o principal caminho para a maior inserção no mercado externo. Por fim, entende-se que este tipo de estratégia tem muito a somar com o desenvolvimento econômico e social dos produtores de cachaça, uma modalidade do agronegócio que envolve diferentes sujeitos, em todas as regiões do País.

\section{Referências}

BRAGA, M. V. F. e KIYOTANI, I. B. A cachaça como patrimônio: turismo cultura e sabor. Revista de Turismo Contemporâneo-RTC, v. 3, n. 2, p. 254-275, jul./dez. 2015.

BRASIL. Ministério da Agricultura, Pecuária e Abastecimento. Decreto no 4062, 21 dez. 2001. Define as expressões "cachaça", "Brasil e "cachaça do Brasil" como indicações geográficas e dá outras providências. Diário Oficial da República Federativa do Brasil, Brasília, DF, 22 de dez.2001.

BRESSER-PEREIRA, L. C. O governo Dilma frente ao "Tripé macroeconômico" e à direita liberal e dependente. Novos Estudos CEBRAP, n. 95, mar. 2013.

CAVALCANTE, T. e LIMA, M. C. A política comercial do governo Lula (2003- 2010): uma análise comparativa das relações comerciais do Brasil com o Mercosul e com o resto do mundo. Século XXI, v. 4, n. 2, 2013.

CERIBELI, D. L. et al. Orientação regional e competitividade do agronegócio da cachaça para a Alemanha e os Estados Unidos. Revista de Politica Agrícola, v. 19, n. 3, p. 21-32, 2010.

CHALITA, M. A. N. e SILVA, C. R. L. Cachaça: desempenho comercial e qualidade de uma bebida genuinamente brasileira. Instituto de Economia AgrícolaIEA, Textos para discussão n. 21, 2010.

CORNELET, J. M. C. A política externa de Dilma Rousseff: contenção na continuidade. Conjuntura Austral, v. 5, n. 24, 2014.

COSTA, N. R. e LAMARCA, I. Os Governos FHC e Lula e a política para a força de trabalho civil do Governo Central Brasileiro. Ciência \& Saúde Coletiva, v. 18, n. 6, p. 1601-1611, 2013.

COUTINHO, E. P. Dinâmica da modernização do setor de produção de aguardente de cana-de-açúcar no Brasil: construindo uma cachaça de qualidade. 2001. Tese de doutorado COPPE, Universidade Federal do Rio de Janeiro, Rio de Janeiro, 2001.
FERNANDES, J. P. T. Elementos de Economia Política Internacional. 2. ed. Coimbra, Portugal: Editora Almedina, 2012.

FIRME, V. A. C. e VASCONCELOS, C. R. F. Identificação de nichos de mercado para países exportadores: uma análise multivariada para o ano de 2011. Análise Econômica, v. 33, n. 64, 2015.

GOMES, E. G., SOUZA, G. D. S. e GAZZOLA, R. Uma análise do comércio internacional de carnes. Revista de Política Agrícola, v. 18, n. 3, p. 8-24, 2009.

HAIR JR., J. F. et al. Análise multivariada de dados. 5. ed. Porto Alegre: Bookman, 2005.

IBRAC. Instituto Brasileiro da Cachaça. 2016. Disponível em: <http://www.ibraccachacas.org/>.

MALHOTRA, N. K. Pesquisa de marketing: uma orientação aplicada. Porto Alegre: Bookman, 2006.

MANLY, B. J. F. Métodos estatísticos multivariados: uma introdução. 3. ed. Porto Alegre: Bookman, 2008.

OLIVEIRA, G. e TUROLLA, F. A. Política Econômica do Segundo Governo FHC: Mudança em Condições Adversas. Tempo Social - Revista de Sociologia da USP, v. 15, n. 2, nov. 2003.

OLIVEIRA, I. T. M. Política comercial e política externa no Brasil: uma análise da estratégia de negociação comercial brasileira (1995-2010). IPEA. Texto Para Discussão 1765, 2012.

OLIVEIRA NETO, V. I. Desafios e oportunidades da cachaça no comércio internacional. Dissertação (Mestrado Profissional em Economia Aplicada). Universidade Federal de Pernambuco: Recife, PE, 2005.

RODRIGUES, W. e BENEDICTO, G. C. Uma análise das políticas do comércio exterior brasileiro nos últimos quinze anos. Revista Eletrônica de Estratégia \& Negócios, v. 2, n. 2, p. 27-51, 2009.

SEBRAE - Serviço Brasileiro de Apoio às Pequenas e Médias Empresas. Cachaça artesanal - SÉRIE ESTUDOS MERCADOLÓGICOS, SEBRAE 2013 Relatório Completo. Disponível em: < http://bis.sebrae. com.br/GestorRepositorio/ARQUIVOS_CHRONUS/ bds/bds.nsf/444c2683e8debad2d7f38f49e848f449/\$F ile/4248.pdf $>$.

OLIVEIRA, G. e TUROLlA, F. A. Política Econômica do Segundo Governo FHC: Mudança em Condições Adversas. Tempo Social - Revista de Sociologia da USP, v. 15, n. 2, nov. 2003.

SILVA, F. R. Na embriaguês da cachaça: produção, imaginário e marketing. 111 f. Dissertação (Mestrado 
em História), Universidade Federal de Uberlândia, Uberlândia, 2009.

SIQUEIRA E. D. e DIAS N. C. "A cachaça é nossa": cultura e ideologia na construção da identidade nacional brasileira. In: VII Jornadas Santiago Wallace de Investigación en Antropología Social. Anais... UBA, Buenos Aires, 2013.

SOUZA, M. A. F. e VALE, F. N. Considerações Estratégicas sobre a Indústria da Cachaça. In: SIMPÓSIO DE ENGENHARIA DE PRODUÇÃO, 11., 2004, Bauru. Anais... Bauru: UNESP, 2004.
SOUZA, R. L. de. Cachaça, vinho, cerveja: da colônia ao século XX. Estudos Históricos, n. 33, p. 1-22, 2004.

TEIXEIRA, R. A. e PINTO, E. C. A economia política dos governos FHC, Lula e Dilma: dominância financeira, bloco no poder e desenvolvimento econômico. Economia e Sociedade, Campinas, v. 21, Número Especial, p. 909-941, dez. 2012.

VERDI, A. R. Dinâmicas e perspectivas do mercado da cachaça. Informações Econômicas, São Paulo, v. 36, n. 2, p. 93-98, fev. 2006. 